\title{
Use of different phosphorus sources by the bloom-forming cyanobacteria Aphanizomenon flos-aquae and Nodularia spumigena
}

\author{
E. Vahtera ${ }^{1, *}$, M. Laamanen ${ }^{1,2}$, J.-M. Rintala ${ }^{1}$ \\ ${ }^{1}$ Finnish Institute of Marine Research, PO Box 2, 00561 Helsinki, Finland \\ ${ }^{2}$ Present address: Ministry of the Environment, PO Box 35, 00023 Government, Finland
}

\begin{abstract}
A laboratory experiment was conducted to study differences in the use of varying phosphorus sources by the bloom-forming filamentous cyanobacteria Aphanizomenon flos-aquae and Nodularia spumigena. Axenic strains were grown in typical bloom-time light regimes under phosphate-replete, added organic phosphorus phosphate-depleted and completely phosphorus-depleted conditions. Responses to the treatments differed clearly. A. flos-aquae growth was dependent on an ample supply of inorganic dissolved phosphorus, whereas $N$. spumigena grew equally well in all treatments. Cellular N:P ratios showed high plasticity for both species and phosphorus deficiency did not seem to affect nitrogen fixation of either species. Regarding bloom formation, the results call attention to the importance of the omnipresence, eurythermal growth and deeper vertical positioning of A. flos-aquae in comparison to N. spumigena. N. spumigena is able to form and sustain bloom biomasses relying on cellular phosphorus storage and effective remineralization of organic phosphorus compounds.
\end{abstract}

KEY WORDS: Filamentous cyanobacteria $\cdot$ Aphanizomenon flos-aquae $\cdot$ Nodularia spumigena Phosphorus source $\cdot$ Phosphorus limitation · Organic phosphorus · Baltic Sea

\section{INTRODUCTION}

In the Baltic Sea, filamentous diazotrophic cyanobacteria form extensive harmful blooms during the summer months when surface waters are depleted in both nitrogen and phosphorus (Kahru et al. 1994, 2000). Conventionally, it has been postulated that as a consequence of excess phosphorus, the nitrogen-fixing cyanobacteria gain competitive advantage. Humaninduced eutrophication of the Baltic Sea has been ongoing since the beginning of the last century (Struck et al. 2000, Voss et al. 2000). The historically long eutrophication process and the characteristic haline stratification have led to widespread anoxic bottoms and subsequent internal loading of phosphorus from the sediments (e.g. Conley et al. 2002). In the Gulf of Finland, it has been observed that, as a result of the increasing water-column phosphorus reserves, phyto- plankton biomass maxima have begun to show a bias towards late summer (Raateoja et al. 2005). This shift may have been caused by the increase in diazotrophic cyanobacteria. Among the most abundant species in conspicuous blooms formed by cyanobacteria are the nitrogen-fixing non-toxic Aphanizomenon flos-aquae (L.) Ralfs and the hepatotoxic Nodularia spumigena Mertens. However, their growth and nitrogen fixation are considered to be phosphorus or trace element limited in the Baltic Sea (Stal et al. 1999, Rydin et al. 2002, Moisander et al. 2003). They vary in their autecological traits (e.g. Huber \& Hamel 1985, Huber 1986, Wallström et al. 1992, Kononen et al. 1996, Lehtimäki et al. 1997, Laamanen \& Kuosa 2005).

Late winter surface-layer phosphate conditions have, to some degree, a determinant effect on the intensity of cyanobacteria blooms (Jansen et al. 2004, Laanemets et al. 2006). Before the onset of thermal 
stratification and the spring bloom in the Baltic Sea, waters are homogenously mixed down to the permanent halocline, at about 60 to $80 \mathrm{~m}$ depth. The wintertime surface water has a lower than average dissolved inorganic nitrogen (DIN) to dissolved inorganic phosphorus (DIP) ratio compared to the average spring bloom phytoplankton demand of 16:1 (Suikkanen et al. 2007). After the establishment of thermal stratification, the spring bloom is terminated by nitrogen limitation and the biomass is sedimented from the surface layer. This creates a situation where an excess of phosphorus is formed in the upper mixed layer.

The excess phosphorus is channelled to nitrogenfixing cyanobacteria through various pathways, e.g. through phosphate uptake during early summer with subsequent growth on intracellular stores (Larsson et al. 2001, Nausch et al. 2004) and through recycling of organic compounds in the planktonic food web (Tamminen 1989, Grönlund et al. 1996, Kangro et al. 2006). Deep-water excess phosphorus is channelled to the cyanobacteria by frontal hydrodynamic processes (Kononen et al. 1996), upwelling (Vahtera et al. 2005) and turbulent mixing (Kononen \& Nômmann 1992) during the growth period. Thus, the excess phosphorus, present in different forms and available through pathways described above, can support bloom formation throughout the growth season. In contrast, it also forms a species selection mechanism through nutrient competition with the prevailing phosphorus sources and phosphorus supply mechanisms and autecological traits of the species as drivers.

Water-column stratification is a critical factor determining the intensity of cyanobacteria blooms at the species level (Kanoshina et al. 2003). In the Gulf of Finland, Aphanizomenon flos-aquae has been observed to thrive in areas of hydrodynamic activity with weaker stratification, while Nodularia spumigena is more dominant in inert, strongly stratified areas (Kononen et al. 1996, Vahtera et al. 2005). Water column stratification affects both the temperature and light climate experienced by the species, but also phosphorus availability and quality at different depths, with DIP concentrations rapidly increasing below the thermocline (Laanemets et al. 2004). The biomass maxima of the 2 bloom-forming species are usually vertically separated, A. flos-aquae having a deeper biomass maximum than N. spumigena (Niemistö et al. 1989, Kononen et al. 1998, Vahtera et al. 2005). Thus, in addition to the effects of the physical environment, the variation in prevalent phosphorus source with depth and sub-basin may affect the species composition of the cyanobacteria blooms.

To further understand phosphorus-related species selection and the main phosphorus sources for blooms of nitrogen-fixing filamentous cyanobacteria in the
Baltic Sea, a laboratory experiment was conducted. Growth, intracellular phosphorus storage capacity and the utilization of a synthetic phosphomonoester as phosphate source between Aphanizomenon flosaquae and Nodularia spumigena were compared.

\section{MATERIALS AND METHODS}

Experimental set-up. The experiment was carried out with a $2 \times 3$ factorial design ( 2 different species, each of which were grown under 3 phosphorus conditions) to reveal differences in growth and phosphorus utilization of the 2 main bloom-forming cyanobacteria species. The 2 $\times 3$ factorial experiment design was chosen so that the effect of different phosphorus sources on both main bloomforming species could be examined. The experiment was carried out using the typical light regimes experienced by the species during bloom periods.

Prior to the experiment, axenic strains of Aphanizomenon flos-aquae (TR183) and Nodularia spumigena (AV1) isolated from blooms in the Baltic Sea (strains courtesy of Academy Professor Kaarina Sivonen) were grown in liquid modified Z8 growth medium without nitrogen and with salt (Z8XS) (Sivonen et al. 1989). The stock cultures were grown at $18^{\circ} \mathrm{C}$ in a

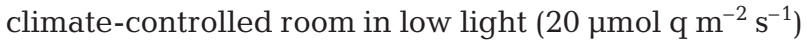
produced by white-light fluorescent tubes (Osram L18 W/22 Lumilux White); the same light source was used during the experiment. Aliquots of each strain were transferred to duplicate acid-washed $1000 \mathrm{ml}$ Erlenmeyer glass experimental units in a laminar flow cabinet.

The experiment consisted of 3 treatments: (1) a control treatment with a replete external dissolved orthophosphate $\left(\mathrm{PO}_{4}{ }^{3-}\right)$ supply $(200 \mu \mathrm{M})$ in the growth medium (P-replete treatment); (2) a treatment with a dissolved orthophosphate-deficient growth medium with an added dissolved organic phosphorus (DOP) source $(25 \mu \mathrm{M}$ glycerol phosphate disodium salt hydrate $\left[\mathrm{C}_{3} \mathrm{H}_{7} \mathrm{Na}_{2} \mathrm{O}_{6} \mathrm{P}\right]$ added to Z8XS medium prepared without phosphorus) (DOP-enriched treatment) and (3) a treatment grown on Z8XS medium with phosphorus completely omitted $(0 \mu \mathrm{M})$ (P-depleted treatment). Upon transfer to the experimental units the strains were washed on a $20 \mu \mathrm{M}$ nylon mesh with treatment-specific medium. The initial biomasses (as chlorophyll a [chl a]) after the transfer to the experimental units were in the range of 18 to $22 \mathrm{\mu g} \mathrm{l}^{-1}$ for Aphanizomenon flos-aquae and 25 to $28 \mu \mathrm{g} \mathrm{l}^{-1}$ for Nodularia spumigena (see Table 1).

The experiment was run for $22 \mathrm{~d}$ at a temperature of $18^{\circ} \mathrm{C}$ in a climate-controlled room with a light:dark cycle of 12:12 h. The units were sampled 3 times a week for concentrations of chl $a$, phosphate phospho- 
rus $\left(\mathrm{PO}_{4}{ }^{3-}\right.$-phosphorus), nitrite and nitrate nitrogen $\left(\mathrm{NO}_{2}{ }^{-}+\mathrm{NO}_{3}{ }^{-}\right.$-nitrogen), particulate nitrogen $(\mathrm{PN})$, particulate phosphorus (PP) and alkaline phosphatase activity (APA). On Day 14 of the experiment, $300 \mathrm{ml}$ of treatment-specific growth medium was added to the experimental units to dilute the cultures. Transmission electron microscope (TEM) images and energy dispersive X-ray analyses were made at the end of the experiment from all the treatments.

The vertical separation of biomass maxima during blooms of the 2 species leads to the species experiencing different light environments. Thus, different light

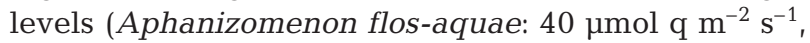

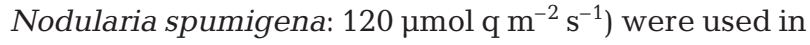
the experiment for the 2 species to establish any differences in phosphorus utilization occurring during these specific conditions. The light levels were derived from species-specific optimal light conditions determined by laboratory experiments (Lehtimäki et al. 1997) and light profiles sampled from the northern Baltic Sea during July (data not shown).

Analytical methods. Duplicate $5 \mathrm{ml}$ samples were taken for chl a analyses. The samples were filtered on GF/F (Whatman) filters that were left to dry in the dark for $15 \mathrm{~min}$, after which the sample was extracted in $10 \mathrm{ml}$ of $96 \%$ ethanol for $24 \mathrm{~h}$. Chl a concentrations were measured after filtration through a GF/F filter to remove any interfering particles with a Jasco 750 spectrofluorometer. The spectrofluorometer was calibrated with pure chl a (Sigma Chemical).

Particulate nutrients were analyzed from $10 \mathrm{ml}$ samples filtered on GF/F filters. Analyses for dissolved inorganic nutrients (analyzed according to Koroleff 1983) were performed from the filtrate of the same samples. The particulate nutrients were analyzed according to the same protocol after boiling the filter in $50 \mathrm{ml}$ of persulfate solution.

APA was measured using the kinetic assay according to Petterson (1980), with modifications as in Kononen et al. (1993). Triplicate $4 \mathrm{ml}$ samples were incubated at $+20^{\circ} \mathrm{C}$ in the dark in acid-washed test tubes. 4-methylumbelliferone-phosphate (MUF-P) was used as fluorogenic substrate analogue at a final concentration of $0.0125 \mu \mathrm{M}$ after determination of the saturation level. The assays were run for 60 min with fluorescence measurements every 15 min. Fluorescence readings were made with a Jasco 750 spectrofluorometer at an excitation wavelength of $365 \mathrm{~nm}$ and an emission wavelength of $460 \mathrm{~nm}$. Fluorescence units were calibrated with MUF-P standard solutions over the range of 0.01 to $1 \mu \mathrm{M}$ and the fluorescence intensity increase in the samples was used to cal- culate the APA given as nmol MUF hydrolyzed $\mathrm{h}^{-1}$. Soluble APA was measured after filtration through a $0.2 \mu \mathrm{m}$ pore-size membrane filter.

Sub-samples for the ultra-structural analyses of the cultured cyanobacteria were preserved with glutaraldehyde ( $2 \%$ final concentration). Cells were concentrated using centrifugation (7 min $3000 \mathrm{rpm}$ [998 $\times$ $g$ ]) and dehydrated in a series of alcohol up to $96 \%$, after which they were embedded in Spurr resin and processed according to Jensen \& Moestrup (1999). A Leica ultracut UCT ultramicrotome was used for thin sectioning. Samples were examined with a JEOL JEM1200EX transmission electron microscope with $60 \mathrm{kV}$ tension and an FEI Tecnai F12 scanning electron microscope equipped with a Gatan 622 camera and an EDAX X-ray microanalysator operated with $120 \mathrm{kV}$ tension.

Statistical analyses. Mixed model repeated measures analyses (PROC MIXED) were used to test for mean differences in chl a concentration, $\mathrm{PN}$ :PP ratio, chl a specific APA (SAPA), PP:chl a ratio and PN:chl a ratio between Aphanizomenon flos-aquae and Nodularia spumigena in the 3 treatments. We tested for the main effects of species and treatment and for the interactions of species-treatment, species-day and treatment-day on the measured parameters. All analyses were conducted with the Statistical Analysis System (SAS V8.02, SAS Institute). Appropriate transformations were applied where necessary to ensure normal distribution of model residuals.

\section{RESULTS}

\section{Chlorophyll a}

For Aphanizomenon flos-aquae, the P-replete treatment had the highest growth rate, whereas the 2 other treatments showed clearly slower growth rates (Table 1). There was less difference in the growth rates between the Nodularia spumigena treatments, with the DOP-enriched treatment having the highest growth rate. Of the 2 species, N. spumigena had a higher growth rate than A. flos-aquae in all cases except in the P-replete treatment.

Table 1. Aphanizomenon flos-aquae and Nodularia spumigena. Means \pm SD of initial biomasses and growth rates in the experimental units

\begin{tabular}{|lcccc|}
\hline \multirow{2}{*}{ Treatment } & \multicolumn{2}{c}{ Chl a $\left(\mu \mathrm{g} \mathrm{l}^{-1}\right)$} & \multicolumn{2}{c|}{ Growth rate $(\mu)$} \\
& A. flos-aquae & $N$. spumigena & A. flos-aquae & $N$. spumigena \\
\hline P-replete & $22.0 \pm 0.0$ & $25.0 \pm 4.2$ & $0.040 \pm 0.001$ & $0.039 \pm 0.002$ \\
DOP-enriched & $21.0 \pm 1.4$ & $26.0 \pm 2.8$ & $0.018 \pm 0.007$ & $0.045 \pm 0.005$ \\
P-depleted & $18.0 \pm 2.8$ & $28.0 \pm 0.0$ & $0.024 \pm 0.009$ & $0.035 \pm 0.009$ \\
& & & & \\
\hline
\end{tabular}


Chl a concentrations showed highly significant differences between species, with Nodularia spumigena having, on average, higher chl a concentrations than Aphanizomenon flos-aquae (Table 2, Fig. 1a,b). Treatments showed nearly significant differences and the species did not have a significant effect on the effect of treatment, i.e. the chl a concentrations of both species reacted in a similar way to the treatments. Both the effect of species and treatment were, however, affected by the elapsed time shown by the significant interaction terms for species and day of experiment and treatment and day of experiment. The significant interaction terms mirror the slower growth of A. flos-aquae in the DOP-enriched and P-depleted treatments.

\section{PN:PP ratio}

The P-depleted treatments of both species showed the most notable increases in the PN:PP ratios
(Fig. 1c,d). Nodularia spumigena had a clearer increase from PN:PP 12:1 at the beginning of the experiment to PN:PP 72:1 at the end of the experiment. The concurrent increase of the Aphanizomenon flos-aquae PN:PP ratio was from 11:1 to $65: 1$. The PN:PP-ratio seemed to increase more prominently for $A$. flos-aquae in the DOP-enriched (increase from 13:1 to 26:1) and in the P-replete (increase from 6:1 to 17:1) treatments than for $N$. spumigena in the DOP-enriched (increase from 13:1 to 22:1) and P-replete (increase from 7:1 to 11:1) treatments.

The PN:PP ratio showed significant differences between species and treatments (Table 2), Aphanizomenon flos-aquae having on average a higher PN:PP ratio than Nodularia spumigena. The significant interaction terms for species and day and treatment and day showed that the effect of the species and treatments were influenced by the passing of time in the experiment. For both species the PN:PP ratios of the Pdepleted treatments increased constantly and more rapidly than for the other treatments.

Table 2. Results for type III tests for fixed effects and the least square means \pm SE for the species and treatments in the mixed model repeated measures analysis for the dependent variables; chl $a$, particulate nitrogen to particulate phosphorus ratio (PN:PP), chl a specific alkaline phosphatase activity (SAPA), particulate phosphorus to chl a ratio (PP:chl a) and particulate nitrogen to chl a ratio (PN:chlorophyll a)

\begin{tabular}{|c|c|c|c|c|c|c|c|}
\hline Effect & Num df & Den df & $F$-value & $\mathrm{p}>F$ & \multicolumn{3}{|c|}{ Least square means and standard errors } \\
\hline \multicolumn{8}{|l|}{ Chl a } \\
\hline Species & 1 & 6 & 87.26 & $<0.0001$ & \multicolumn{2}{|c|}{ A. flos-aquae } & migena \\
\hline Treatment & 2 & 6 & 4.89 & 0.0550 & \multicolumn{2}{|c|}{$4.66 \pm 0.10$} & $5.94 \pm 0.10$ \\
\hline Species $\times$ Treatment & 2 & 6 & 4.11 & 0.0750 & P-replete & DOP-enriched & P-depleted \\
\hline Species $\times$ Day & 8 & 64 & 2.42 & 0.0236 & $5.60 \pm 0.12$ & $5.17 \pm 0.12$ & $5.12 \pm 0.12$ \\
\hline Treatment $\times$ Day & 16 & 64 & 3.12 & 0.0006 & & & \\
\hline \multicolumn{8}{|l|}{$\mathrm{PN}: \mathrm{PP}$} \\
\hline Species & 1 & 6 & 8.81 & 0.0250 & \multicolumn{2}{|c|}{ A. flos-aquae } & \multirow{2}{*}{$\begin{array}{l}\text { spumigena } \\
82 \pm 0.03\end{array}$} \\
\hline Treatment & 2 & 6 & 236.20 & $<0.0001$ & \multicolumn{2}{|c|}{$2.99 \pm 0.03$} & \\
\hline Species $\times$ Treatment & 2 & 6 & 3.52 & 0.0973 & P-replete & DOP-enriched & P-depleted \\
\hline Species $\times$ Day & 9 & 72 & 2.37 & 0.0210 & $2.31 \pm 0.04$ & $2.91 \pm 0.04$ & $3.55 \pm 0.04$ \\
\hline Treatment $\times$ Day & 18 & 72 & 5.83 & $<0.0001$ & & & \\
\hline \multicolumn{8}{|l|}{ SAPA } \\
\hline Species & 1 & 6 & 0.06 & 0.8174 & \multicolumn{2}{|c|}{ A. flos-aquae } & migena \\
\hline Treatment & 2 & 6 & 271.84 & $<0.0001$ & \multicolumn{2}{|c|}{$1.03 \pm 0.001$} & $=0.001$ \\
\hline Species $\times$ Treatment & 2 & 6 & 8.00 & 0.0203 & P-replete & \multirow{2}{*}{$\begin{array}{c}\text { DOP-enriched } \\
1.03 \pm 0.001\end{array}$} & P-depleted \\
\hline Species $\times$ Day & 7 & 56 & 3.87 & 0.0017 & $1.01 \pm 0.001$ & & $1.05 \pm 0.001$ \\
\hline Treatment $\times$ Day & 14 & 56 & 8.89 & $<0.0001$ & & & \\
\hline \multicolumn{8}{|l|}{ PP:chl a } \\
\hline Species & 1 & 6 & 54.25 & 0.0003 & \multicolumn{2}{|c|}{ A. flos-aquae } & migena \\
\hline Treatment & 2 & 6 & 92.09 & $<0.0001$ & \multicolumn{2}{|c|}{$0.21 \pm 0.01$} & $=0.01$ \\
\hline Species $\times$ Treatment & 2 & 6 & 12.27 & 0.0076 & P-replete & \multirow{2}{*}{$\begin{array}{c}\text { DOP-enriched } \\
0.26 \pm 0.02\end{array}$} & P-depleted \\
\hline Species $\times$ Day & 8 & 63 & 4.11 & 0.0005 & $0.47 \pm 0.02$ & & $0.17 \pm 0.02$ \\
\hline Treatment $\times$ Day & 16 & 63 & 3.32 & 0.0003 & & & \\
\hline \multicolumn{8}{|l|}{ PN:chl a } \\
\hline Species & 1 & 6 & 62.93 & 0.0002 & \multicolumn{2}{|c|}{ A. flos-aquae } & migena \\
\hline Treatment & 2 & 6 & 0.98 & 0.4295 & \multicolumn{2}{|c|}{$4.03 \pm 0.14$} & $=0.14$ \\
\hline Species $\times$ Treatment & 2 & 6 & 2.43 & 0.1689 & P-replete & DOP-enriched & P-depleted \\
\hline Species $\times$ Day & 8 & 64 & 3.09 & 0.0053 & $4.62 \pm 0.17$ & $4.84 \pm 0.17$ & $4.95 \pm 0.17$ \\
\hline Treatment $\times$ Day & 16 & 64 & 2.43 & 0.0062 & & & \\
\hline
\end{tabular}



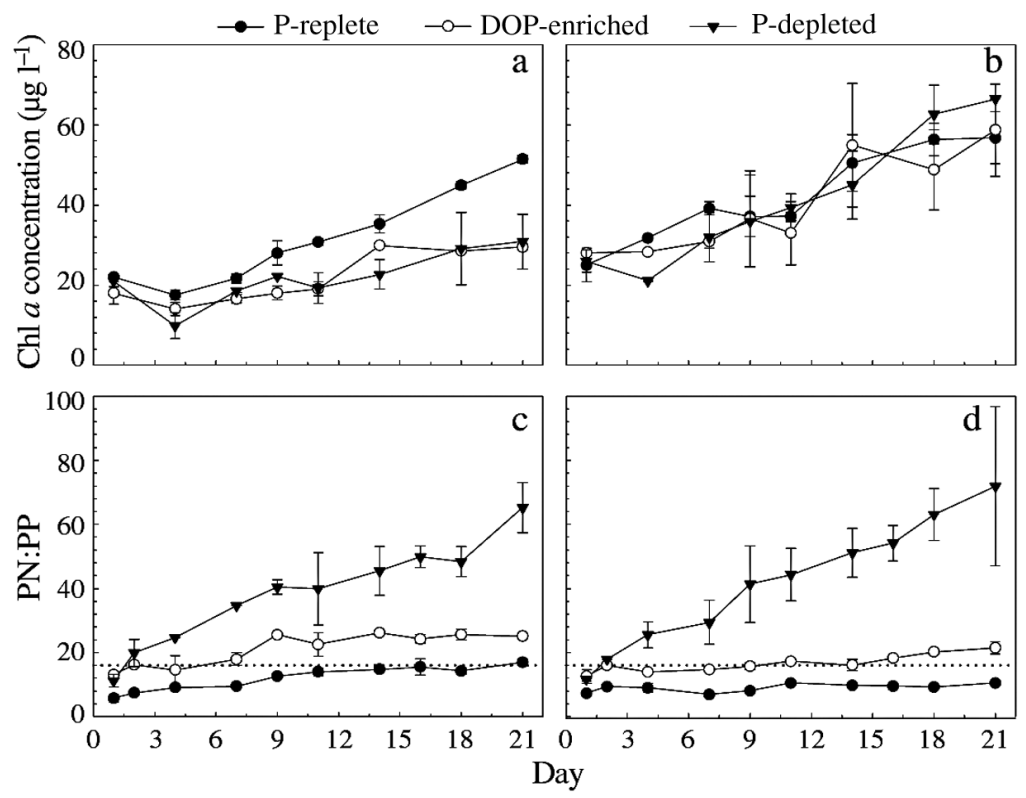

Fig. 1. $(\mathrm{a}, \mathrm{b}) \mathrm{Chl}$ a concentrations and $(\mathrm{c}, \mathrm{d})$ particulate nitrogen to particulate phosphorus ratios (PN:PP) during the experiment for $(\mathrm{a}, \mathrm{c})$ Aphanizomenon flos-aquae and (b,d) Nodularia spumigena in phosphorus-replete (P-replete), phosphorus-deficient with an organic phosphorus addition (DOP-enriched) and phosphorus-depleted (P-depleted) treatments. Error bars indicate $\pm \mathrm{SD}$. (c,d) Dotted line shows the Redfield ratio of 16:1

\section{SAPA and soluble APA}

SAPA indicates culture-specific phosphorus stress. The species did not show a significant difference in SAPA (Table 2), which is probably partly due to the large variation in the Nodularia spumigena treatments (Fig. 2b). The treatments nevertheless evoked clearly statistically different responses, and all but the Preplete treatment showed increasing SAPA during the experiment (Fig. 2a,b) due to increasing phosphorus deficiency of the cultures. Both species reacted immediately to external phosphorus deficiency by increasing the enzyme activity (Figs. 2a,b \& 3). Aphanizomenon flos-aquae showed a strong SAPA increase in the P-depleted treatment towards the end of the study after Day 14 , which is mirrored by the significant species and day interaction term in the model (Table 2).

The species affected the response to treatment statistically significantly, as

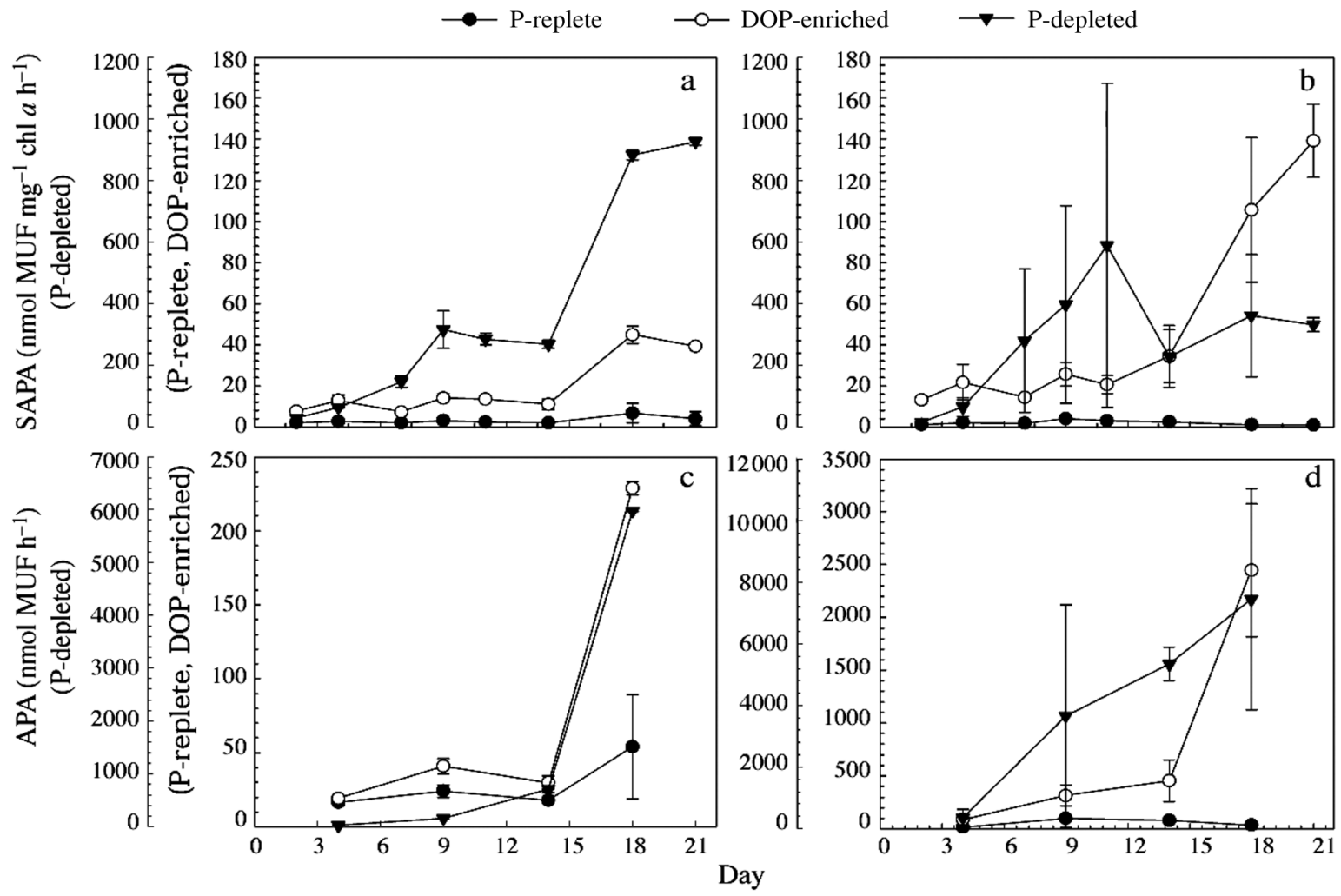

Fig. 2. (a,b) Chl a specific alkaline phosphatase activity (SAPA) and (c,d) soluble alkaline phosphatase activity (APA) during the experiment for $(\mathrm{a}, \mathrm{c})$ Aphanizomenon flos-aquae and $(\mathrm{b}, \mathrm{d})$ Nodularia spumigena in phosphorus-replete (P-replete), phosphorusdeficient with an organic phosphorus addition (DOP-enriched) and phosphorus-depleted (P-depleted) treatments. Error bars indicate $\pm \mathrm{SD}$ 


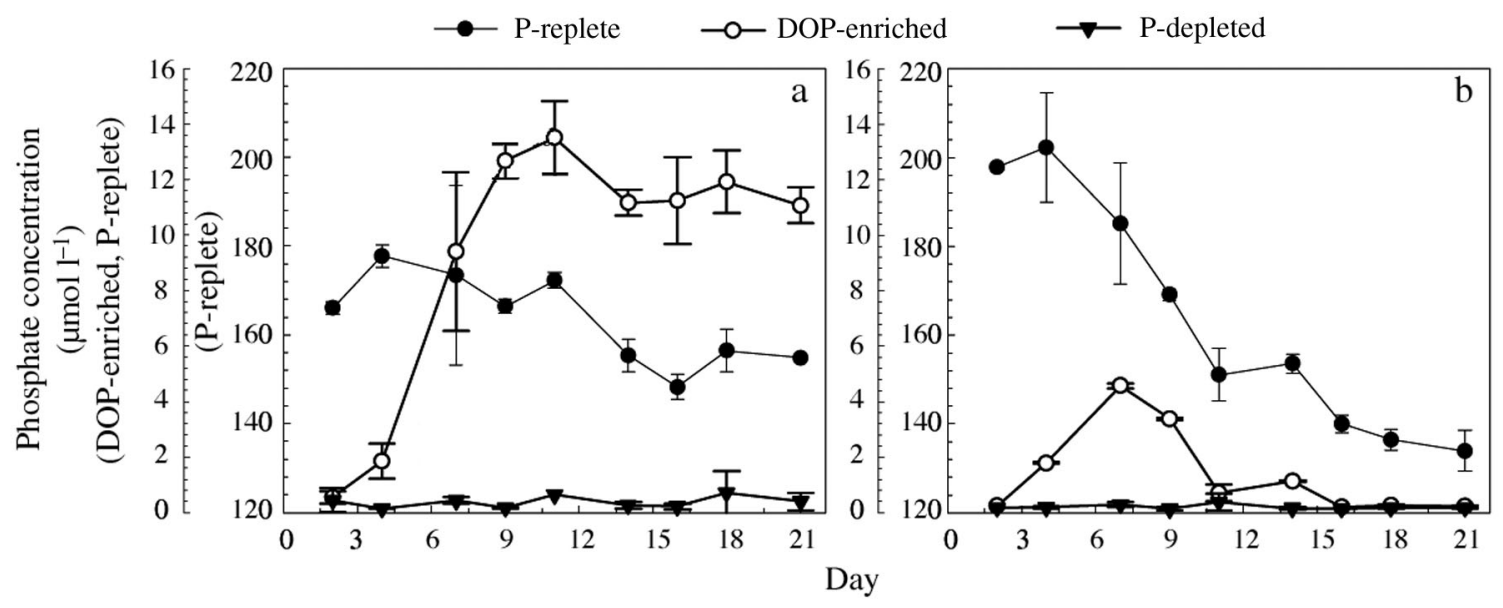

Fig. 3. Phosphate $\left(\mathrm{PO}_{4}\right)$ concentrations during the experiment for (a) Aphanizomenon flos-aquae and (b) Nodularia spumigena in phosphorus-replete (P-replete), phosphorus-deficient with an organic phosphorus addition (DOP-enriched) and phosphorusdepleted (P-depleted) treatments. Error bars indicate \pm SD

shown by the species and treatment interaction term. Nodularia spumigena SAPA in the DOP-enriched treatment showed a more pronounced increase than that of the Aphanizomenon flos-aquae DOP-enriched treatment, indicating stronger phosphorus stress. Generally, A. flos-aquae had on average a higher SAPA in the P-depleted treatment (A. flos-aquae: $364.35 \mathrm{nmol} \mathrm{MUF} \mu^{-1}$

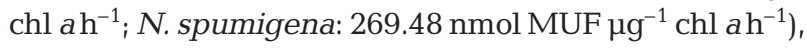
while $N$. spumigena had on average a higher SAPA in the DOP-enriched treatment ( $A$. flos-aquae:18.71 nmol MUF $\mu^{-1} \mathrm{chl} \mathrm{ah}^{-1}$; N. spumigena: $46.69 \mathrm{nmol} \mathrm{MUF} \mu \mathrm{g}^{-1}$ $\mathrm{chl} a \mathrm{~h}^{-1}$ ). Both species showed negligible SAPA in the Preplete treatment throughout the study, reflecting the good phosphorus nutritive status of the cells.

Soluble APA was highest in the P-depleted treatments, and lowest in the P-replete treatments (Fig. 2c,d), in accordance with general levels of SAPA. The Nodularia spumigena P-depleted and DOPenriched treatments had consistently higher levels of soluble APA than the corresponding Aphanizomenon flos-aquae treatments, even though the P-depleted treatment showed large variation. The percentages of soluble to total APA varied between 3 to 35 and 19 to $67 \%$ for A. flos-aquae and N. spumigena, respectively. This indicates possibly a larger fraction of excess enzyme synthesis for $N$. spumigena.

\section{Dissolved inorganic nutrients}

Phosphate concentrations in the P-replete treatments declined more rapidly for Nodularia spumigena (Fig. 3). However, phosphate did not decrease to levels where it would have affected the nutritive status of the cells for either species shown by constantly low SAPA.
The P-depleted treatments of both species showed consistently low phosphate concentrations. Thus, growth conditions in the P-replete or P-depleted treatments regarding phosphorus supply did not markedly change during the experiment.

Phosphate concentrations increased in the DOPenriched Aphanizomenon flos-aquae treatment for the first $8 \mathrm{~d}$ of the experiment, after which the concentration stabilized at around 11 to $12 \mu \mathrm{M}$. Phosphate concentrations in the DOP-enriched Nodularia spumigena treatment increased initially until Day 7 of the experiment, and subsequently decreased to levels comparable to the P-depleted treatment. The completely depleted phosphate concentrations and rapidly increasing SAPA for the N. spumigena DOP-enriched treatment imply substrate limitation of hydrolysis.

Nitrite and nitrate concentrations were consistently low $(<0.5 \mu \mathrm{M})$ (data not shown) for all but the Aphanizomenon flos-aquae P-replete and P-depleted treatments, which showed a slight variation in DIN concentrations $(0.5$ to $2.0 \mu \mathrm{M})$.

\section{PP:chl a ratio}

Both species showed their lowest PP:chl a ratios in the P-depleted treatments. The DOP-enriched treatments had intermediate, and the P-replete treatments the highest PP:chl a ratios (Fig. 4a,b). The differences between species and treatments were significant (Table 2). Aphanizomenon flos-aquae had on average a lower PP:chl a ratio compared with Nodularia spumigena.

The species and treatment interaction term was also significant, implying differing responses of the species to the treatments. Nodularia spumigena had higher ratios 

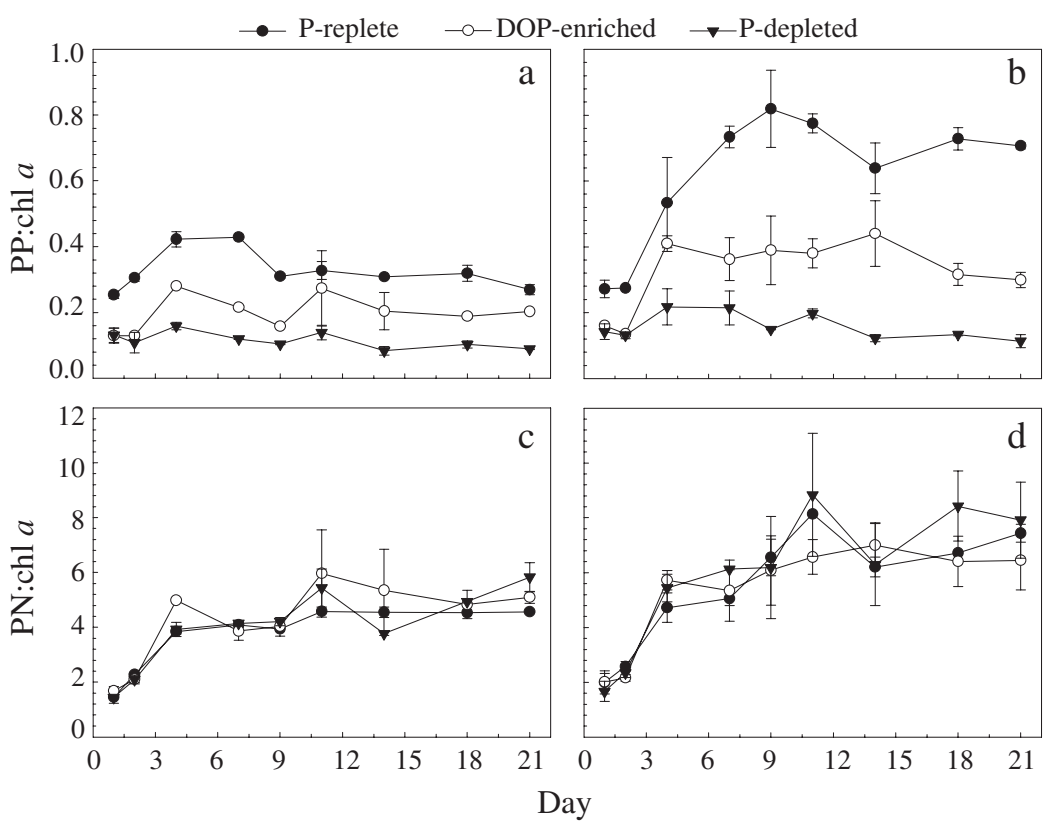

Fig. 4. (a,b) Particulate phosphorus to chl a ratio (PP:chl a) and (c,d) particulate nitrogen to chl a ratio ( $\mathrm{PN}: \mathrm{chl}$ a) during the experiment for $(\mathrm{a}, \mathrm{c})$ Aphanizomenon flos-aquae and (b,d) Nodularia spumigena in phosphorus-replete (P-replete), phosphorus-deficient with an organic phosphorus addition (DOP-enriched) and phosphorus-depleted (P-depleted) treatments. Error bars indicate $\pm \mathrm{SD}$

in both the P-replete and DOP-enriched treatments. However, both species had similar PP:chl a ratios in the P-depleted treatment (Aphanizomenon flos-aquae: $0.12 \pm 0.03 ;$ N. spumigena: 0.16 \pm 0.04 ) (Fig. 4a,b).

\section{PN:chl a ratio}

Nodularia spumigena $\mathrm{PN}$ :chl a ratios were higher than the corresponding Aphanizomenon flos-aquae values (Fig. 4c,d) and the difference between species was significant, whereas no treatment effects were found (Table 2). The ratios increased for both species during the experiment, but dilution of the cultures on Day 14 of the experiment seemed to have a decreasing effect on the ratios in both species. The ratio stabilized more or less after Day 4 of the experiment for both species in all treatments. The average $\mathrm{PN}$ :chl a ratio for all A. flos-aquae and $N$. spumigena treatments was $4.7 \pm$ 0.7 and $6.8 \pm 1.0$, respectively.

\section{TEM images and energy dispersive X-ray analyses}

The polyphosphate granules were distinctly small and characteristically electron-dense, appearing as dark grains in the images (Fig. 5). The granules were on average only a few nm in diameter and were evenly distributed in both vegetative cells and heterocytes. Energy-dispersive X-ray analyses from an area abundant in electron-dense granules (Fig. 6a) and from a gas vacuole (Fig. 6b) taken from a Nodularia spumigena P-replete unit shows a distinct phosphate peak that is overlapped by an $\alpha$-osmium peak at approximately $2 \mathrm{KeV}$ in the area of electron-dense granules. The spectrum from the gas vacuole devoid of electrondense granules shows no phosphate.

The P-replete control treatments of both species had abundant polyphosphate granules distributed throughout the cells (Fig. 5a,d). The DOP-enriched and P-depleted treatments showed successively less polyphosphate granules than the P-replete treatments (Fig. 5b,c,e,f).

\section{DISCUSSION}

The present study illustrates the phosphorus utilization of the 2 main bloomforming nitrogen-fixing filamentous cyanobacteria species from the Baltic Sea during bloom conditions. Our aim was to investigate the possible effects of phosphorus source on species-specific phosphorus utilization and the potential of the principal phosphorus source as a species selection mechanism during bloom formation and sustenance.

The growth of the 2 main bloom-forming species, Nodularia spumigena and Aphanizomenon flos-aquae, responded with distinct patterns to the phosphorus treatments in the simulated bloom-time light regimes. A. flos-aquae growth suffered from the lack of available abundant dissolved phosphate. The growth rates of both the P-depleted and DOP-enriched treatments were slower than that of the P-replete treatment, which was of the same magnitude as that in all the $N$. spumigena treatments.

The experiment was done in batch cultures; thus, the growth environment changes with time as phosphate is utilized and biomass accumulates. The growth environment, regarding phsophorus supply, in the Preplete and $\mathrm{P}$-depleted treatments for both species were most likely not markedly affected by the density effect. Phosphate concentrations in the P-depleted treatments were constantly low (Fig. 3) and the particulate phosphorus concentrations for both species were stable (data not shown). The P-replete treatments showed marked drawdown of phosphate, especially the Nodularia spumigena treatment, but the absolute 

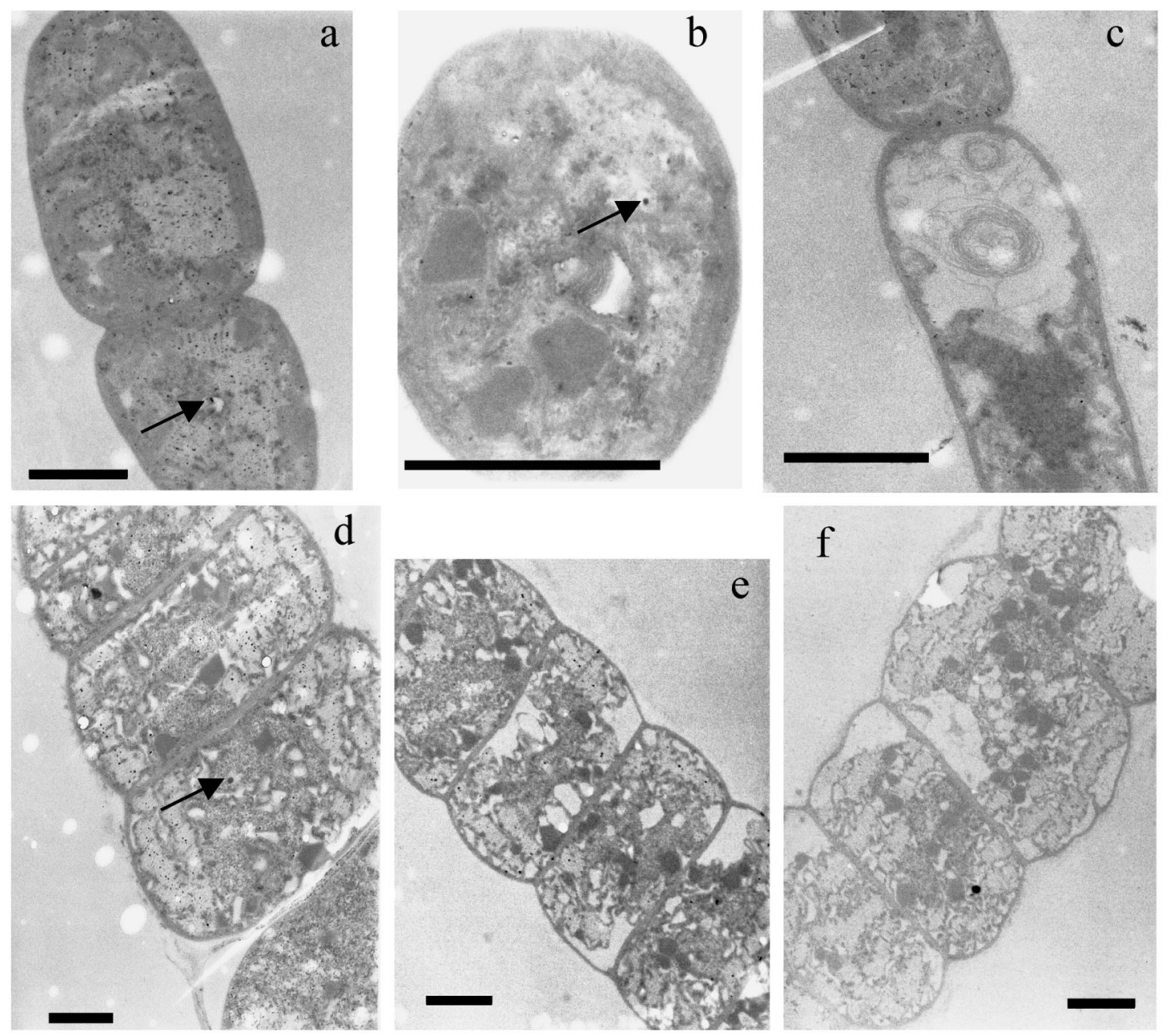

Fig. 5. Aphanizomenon flos-aquae and Nodularia spumigena. Transmission electron microscope images of cells from the experimental treatments. (a) A. flos-aquae phosphorus-replete control, (b) A. flos-aquae phosphorus-depleted treatment with added organic phosphorus, (c) A. flos-aquae phosphorus-depleted treatment, (d) N. spumigena phosphorus-replete control, (e) N. spumigena phosphorus-depleted treatment with added organic phosphorus and (f) N. spumigena phosphorus-depleted treatment. Polyphosphate bodies appear as black grains (black arrows). Scale bar $=1 \mu \mathrm{m}$
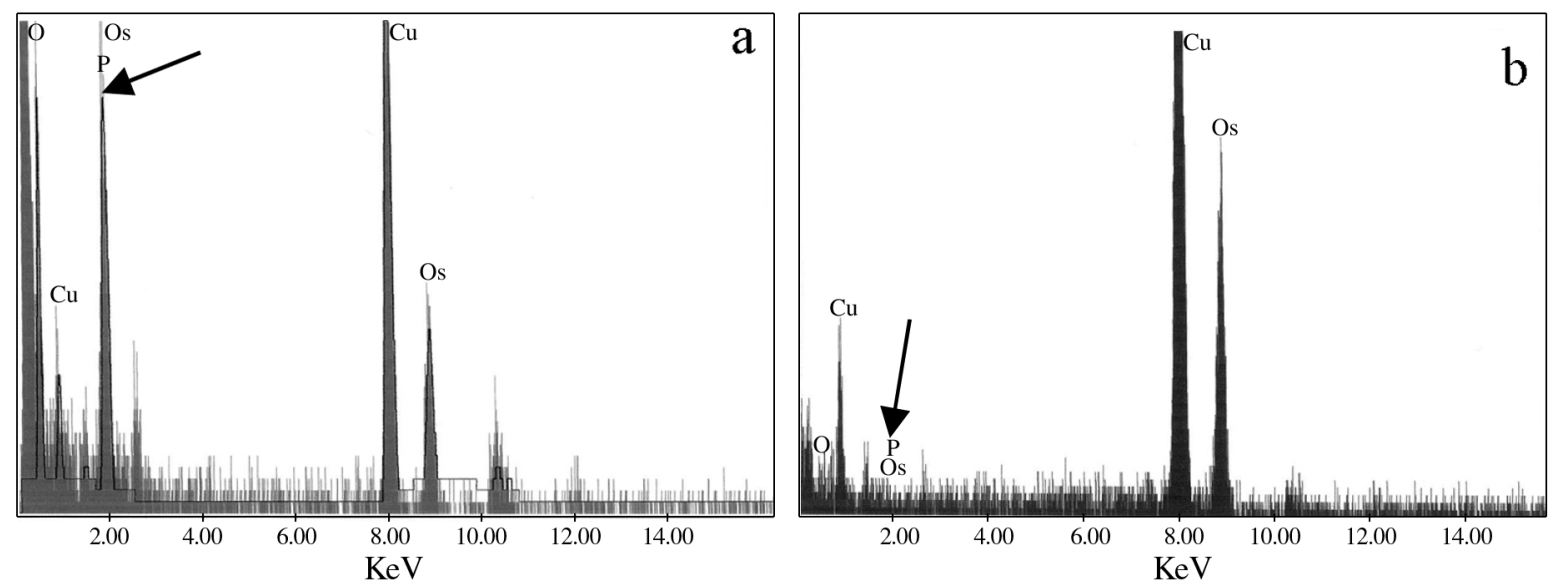

Fig. 6. Energy dispersive X-ray analysis elemental spectra from (a) area with electron-dense granules, and (b) gas vacuole of a Nodularia spumigena control treatment vegetative cell. The $y$-axis shows relative intensity. Diameter of the X-ray beam was $500 \mathrm{~nm}$. Arrows show the position of the phosphorus peak 
concentrations were still so high at the end of the experiment that they most likely did not affect phosphate availability of the experimental units, as also indicated by constantly low SAPA. The DOP-enriched units, especially that of $N$. spumigena, showed clear signs of substrate limitation after Day 14 of the experiment, with depleted phosphate concentrations and rapidly increasing SAPA. While, A. flos-aquae did not show as clear an increase in SAPA and phosphate concentrations were not depleted. A. flos-aquae SAPA and $\mathrm{N}: \mathrm{P}$ ratios indicated a phosphorus deficiency, but an affinity constraint for phosphorus uptake, as shown by the steady phosphate concentrations, caused continuous phosphorus stress. N. spumigena was able to satisfy its phosphorus requirements as long as substrate was availbale for hydrolysis. The quicker drawdown of phosphate in the $N$. spumigena DOP-enriched treatment might be a density effect. However, the faster growth, when compared to A. flos-aquae, nevertheless indicates a more efficient use of the available phosphorus source.

The fact that Aphanizomenon flos-aquae showed less efficient growth in both phosphorus-deficient treatments places it in an inferior position in relation to Nodularia spumigena in the utilization of phosphate from hydrolysable organic compounds during bloom periods. Regarding species selection during bloom formation, our results point to the importance of the omnipresence and eurythermal growth, and thus larger inoculum for summer blooms of A. flos-aquae. Populations of A. flos-aquae are present throughout spring and early summer in free water (e.g. Laamanen \& Kuosa 2005), constituting thus a larger bloom inoculum than that of N. spumigena, and allowing populations with less efficient growth to still form substantial bloom biomasses. N. spumigena biomass is temporally and spatially more patchy (Kononen \& Nômmann 1992, Laamanen \& Kuosa 2005); it is observed later in the year in free water than A. flos-aquae and its growth is more stenothermal, thus partly not being able to grow efficiently at deeper depths where dissolved phosphate is available (e.g. Lehtimäki et al. 1997).

In our experiment Nodularia spumigena grew best, but at similar growth rates as in the other treatments, on organic phosphorus. N. spumigena seems to have developed an adaptation to efficient growth in conditions of phosphate deficiency in systems that nevertheless have abundant phosphorus available in other forms. The fraction of the DOP pool during summer in the surface layer of the Baltic Sea may represent 70 to $100 \%$ of the total phosphorus (Kononen \& Nômmann 1992); Grönlund et al. (1996) observed that during short (40 min) incubations, more than half of the added phosphate ended up in the DOP pool. Nausch \& Nausch (2004) estimated that 4 to $43 \%$ of DOP would be bioavailable. Our results support the assumption that $N$. spumigena, located typically close to the surface in an environment where phosphorus occurs predominantly in particulate and dissolved organic forms during summer, presumably satisfies its phosphorus needs through remineralization pathways.

The TEM images showed a gradual decreasing trend of possibly identified polyphosphate granules from Preplete to DOP-enriched to P-depleted treatments (Fig. 5). However, the size and distribution of the polyphosphate granules were uncharacteristic, and they were rather small in comparison to an earlier report (Janson et al. 1994). For Anabaena flos-aquae (Lyngb.) Bréb, it has been observed that phosphorus is stored as sugar phosphorus under nitrogen-fixing conditions (Thompson et al. 1994), which might explain the peculiar form and distribution of the phosphorusrich granules in our strains that also relied on nitrogen fixation as the sole nitrogen source.

The presence of phosphorus in areas dense with supposed polyphosphate granules was verified with energy-dispersive X-ray analysis. Phosphorus produces a peak in the spectrum at approximately $2 \mathrm{KeV}$ (Fig. 6a). Osmium, which is used as a fixative in the sample preparation to increase contrast, produces an $\alpha$-peak with nearly the same energy as phosphorus, but it also produces a $\beta$-peak at approximately $9 \mathrm{KeV}$ (Fig. 6a,b). A spectrum from a gas vacuole (Fig. 6b), devoid of the supposed polyphosphate granules, still shows the osmium $\beta$-peak, indicating the presence of osmium. The osmium $\alpha$-peak and the phosphorus peak are not preserved, indicating that the overlapping osmium and phosphorus peaks are indeed related to the presence of phosphorus and not of only osmium.

The PN:PP ratios in the experiment showed distinct patterns between treatments. The particulate phosphorus analyses in the experiment include both intracellular and surface-adsorbed phosphate. The Pdepleted treatments showed the most distinct increase in PN:PP ratios (Fig. 1c,d). This was caused by the decrease in cellular phosphorus stores (cf. Fig. 5c,f), but possibly also due to the increase in some nitrogenous compound in the cells, reflected by the increasing $\mathrm{PN}$ :chl a ratios (Fig. 4c,d). In our experiment, the strains relied completely on nitrogen fixation, and the P-depleted treatments of both species accumulated nitrogen in relation to biomass in a similar manner to the other treatments (Fig. 4c,d), indicating high plasticity of nitrogen fixation in relation to phosphorus stress. Neither the source of phosphorus nor the intensity of phosphorus starvation significantly affected the nitrogen fixation ability of the cells. Previous field and experimental studies have noted that nitrogen fixation of filamentous heterocyte possessing cyanobacteria is stimulated by phosphorus addition and general growth 
promoting factors (Huber 1986, Lehtimäki et al. 1997, Moisander et al. 2003). Based on our results it seems, nevertheless, as if nitrogenase synthesis is rather robust in relation to cellular phosphorus depletion. The increase in PN:PP ratios to >60:1 did not seem to affect nitrogen fixation to a large extent.

The P-replete treatments of both species showed constantly low PN:PP ratios, more so for Nodularia spumigena. Aphanizomenon flos-aquae showed a slight but constant increase in the PN:PP ratio. The increasing $\mathrm{PN}$ :PP ratio in the $A$. flos-aquae P-replete treatment might not be a sign of usage of cellular phosphorus stores but may indicate accumulation of nitrogen storage compounds and an equilibrium state in phosphorus storage.

The Nodularia spumigena P-replete treatment showed a very low PN:PP ratio throughout the experiment $(<11: 1)$. The particulate nutrient analysis used was not able to discriminate between surfaceadsorbed and intracellular phosphorus. Sañudo-Wilhelmy et al. (2004) and Fu et al. (2005a) have found that true intracellular phosphorus concentrations are much smaller than anticipated from bulk particulate nutrient analyses due to ample surface adsorption of phosphate. Intracellular N:P ratios are up to 1.2 to 2 times higher than measured bulk ratios. This would yield an average $\mathrm{N}: \mathrm{P}$ ratio of 13.2 to 22 for the N. spumigena P-replete treatment. Fu et al. (2005a) observed that the amount of surface-adsorbed phosphorus depends on the physiological state and phosphorus demand of the cell, with actively growing and phosphorus-depleted cells having less surfaceadsorbed phosphate. We can assume that the P-replete treatments had an ample supply of phosphate (Fig. 3), and thus the amount of surface-adsorbed phosphate would be in the upper part of the range. This would mean that $N$. spumigena and Aphanizomenon flosaquae have cellular N:P ratios exceeding the Redfield ratio under conditions when phosphate is not limiting. The P-depleted treatments reached $\mathrm{N}: \mathrm{P}$ ratios of approximately $70: 1$; according to the range given by Fu et al. (2005a), these values would yield true intracellular N:P ratios of approximately 80 to $140: 1$, of which the lower values in the range are more probable, since nutrient-depleted cells utilize to some degree the surface-adsorbed phosphate. Nevertheless, the results show that the $\mathrm{N}$ :P ratio of $N$. spumigena and A. flos-aquae has high plasticity, and that efficient growth can occur at N:P ratios far exceeding the Redfield ratio of $16: 1$.

Nodularia spumigena showed a significantly higher PN:chl a ratio than Aphanizomenon flos-aquae (Table 2), indicating a more efficient nitrogen fixation under the experimental conditions. This may have been caused by the different light levels used in the experiment. Nitrogen fixation has been observed to depend on photon flux density, and colonies adapted to lower light levels did not increase nitrogen fixation to levels equalling colonies adapted to high light conditions, even when transferred to higher light conditions (Evans et al. 2000). Our cultures were pre-accli-

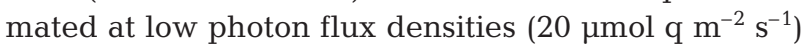
for weeks; the rapid initial increase in the PN:chl a ratios indicates the high plasticity of the nitrogen fixation capacities of the strains used.

However, it is also possible that the higher PN:chl a ratios for Nodularia spumigena would have been caused by a lower C:chl a ratio due to the higher light levels used, thus increasing the PN:chl a ratio in excess in relation to the Aphanizomenon flos-aquae treatments. We can consider particulate phosphorus a rather stable parameter in the P-depleted treatments since the treatments received no other phosphorus source than the cellular phosphorus present at the start of the experiment. The A. flos-aquae PP:chl a ratio was only slightly higher than that of $N$. spumigena. At the beginning of the experiment upon transfer from the stock cultures A. flos-aquae was transferred to

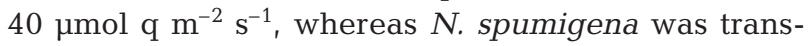
ferred to $120 \mu \mathrm{mol} \mathrm{q} \mathrm{m} \mathrm{m}^{-2} \mathrm{~s}^{-1}$. As a consequence, we could anticipate a more pronounced decrease in the relative chl a amount per cell for $N$. spumigena. The $\mathrm{PP}: \mathrm{chl}$ a ratios for the $\mathrm{P}$-depleted treatments nevertheless do not show any decrease, which would be a sign of decreased C:chl a ratio, and there is no marked difference between the species. Thus, this implies that the changes in the PP:chl $a$ and $\mathrm{PN}$ :chl a ratios would mainly be because of changes in cellular nutrient reserves and not the change in relative cellular chl $a$ content in relation to light intensity.

The P-replete Nodularia spumigena PP:chl a ratio shows a very strong initial accumulation of cellular phosphorus, after which a stabilization is seen at a rather high PP:chl a ratio (approximately 0.7 ). In the Preplete Aphanizomenon flos-aquae treatment the PP:chl a ratio stabilizes at approximately 0.3. Both species seem to be very efficient in cellular phosphorus storage, in accordance with earlier reports (Kromkamp 1987). Nevertheless, N. spumigena seems to have a relatively higher cellular phosphorus quota. A similar pattern as found with the other treatments is reflected in the DOP-enriched treatments. A. flos-aquae shows slightly higher and increasing PN:PP ratios and slightly lower PP:chl a ratios throughout the experiment. Even though the PP:chl a ratio is somewhat compromised by the possibility of deviant $\mathrm{C}$ :chl a ratios due to different light levels used, the higher growth rates and lower $\mathrm{PN}$ :PP ratios for $N$. spumigena in the DOP-enriched and P-depleted treatments emphasise the better capacity of N. spumigena to use the synthetic phosphomo- 
noester and cellular phosphorus stores as phosphorus sources for growth under the experimental conditions.

Light intensity does not affect phosphorus uptake in cyanobacteria as such, but may stimulate it and lead to increased production of polyphosphate storage products (e.g. Fu et al. 2005b and references therein). This is, along with lower $\mathrm{C}$ :chl a ratios, a potential explanation for the higher cellular phosphorus quota (expressed as PP:chl a ratio) of Nodularia spumigena in the experiment. As the biomass maxima of the 2 species are vertically separated during blooms, this general observation is likely to apply in the field as well, with $N$. spumigena phosphorus uptake being stimulated by high light environments and the higher cellular phosphorus quota compensating for the relative scarcity of phosphate.

The P-depleted treatments clearly showed the highest SAPA, and for both species activities started to increase concurrently at the beginning of the experiment (Fig. $2 \mathrm{a}, \mathrm{b})$. SAPA for both species seemed to be repressed by the absence of dissolved phosphate, but also the cellular phosphorus content showed simultaneous decrease with increasing SAPA, especially in the Nodularia spumigena DOP-enriched treatment (Figs. 2a,b \& 4a,b). N. spumigena alkaline phosphatase seemed to leak more readily into the growth medium than it did for Aphanizomenon flos-aquae (Fig. 2c,d). This leads in nature to a poorer ratio of acquired phosphate to produced enzyme amount, since most probably heterotrophic bacteria and smaller phototrophs will out-compete the filamentous cyanobacteria in phosphorus uptake when nitrogen and carbon are in sufficient supply.

During summer, DIN is depleted from the surface waters in the Baltic Sea, and phytoplankton production is generally nitrogen-limited (e.g. Granéli et al. 1990, Moisander et al. 2003); bacterial production is limited by the supply of carbon, nitrogen and phosphorus in the proper ratios (Heinänen \& Kuparinen 1992, Kuparinen \& Heinänen 1993). Thus, in summer, during periods when other phytoplankton are nitrogen-limited and bacteria are limited by the resource ratios, available phosphorus from inorganic and organic pools might be channelled to the diazotrophic cyanobacteria despite excess leakage of alkaline phosphatase. However, filamentous cyanobacteria have been usually reported to be responsible for only a minor fraction of phosphorus uptake during blooms (Grönlund et al. 1996, Nausch et al. 2004). Their phosphorus demand in any case seems to be small, and the $\mathrm{N}: \mathrm{P}$ ratios display remarkable plasticity, as growth rates can withstand increases in cellular N:P ratios of at least up to 80:1 (Fig. 1c,d).

Nodularia spumigena SAPA varied greatly between replicates in the $\mathrm{P}$-depleted treatment, which is thus somewhat ambiguous in relation to Aphanizomenon flos-aquae. A. flos-aquae had a more consistent re- sponse, with a strong increase at the end of the experiment. On average, A. flos-aquae SAPA was higher in the P-depleted treatment (364.35 nmol MUF $\mathrm{mg}^{-1} \mathrm{chl} \mathrm{a}$ $\mathrm{h}^{-1}$ ) than the corresponding $N$. spumigena SAPA (269.48 nmol MUF $\mathrm{mg}^{-1} \mathrm{chl} \mathrm{a}^{-1}$ ). The values observed are generally an order of magnitude higher than ambient SAPA activities measured in the field during a cyanobacteria bloom dominated by A. flos-aquae, and up to 2 times higher than the maximum values measured during the same bloom event (Grönlund et al. 1996).

Both species showed slightly elevated SAPA in the DOP-enriched treatments (Fig. 2a,b), along with increasing phosphate concentrations (Fig. 3). The increasing phosphate concentrations indicate efficient liberation of phosphate from the synthetic phosphomonoester. Nodularia spumigena was able to utilize the liberated phosphate efficiently, as seen by declining concentrations after Day 7 of the experiment, but Aphanizomenon flos-aquae had a clear affinity constraint at phosphate concentrations of approximately 11 to $12 \mathrm{mmol} \mathrm{m}^{-3}$. N. spumigena showed rapidly increasing SAPA after the depletion of phosphate from the medium, indicating efficient repression of enzyme synthesis by the absence of the product. Stoecker et al. (2005) found elevated APA activities during a cyanobacteria bloom dominated by $N$. spumigena, and they concluded that colonies and aggregates of cyanobacteria can be important sites of hydrolytic activity in the Baltic Sea, affecting nutrient regeneration. Panosso \& Granéli (2000), on the other hand, noted that $N$. spumigena was unable to utilize dissolved organic matter derived by filtration from river water as a phosphorus source. The quality of the organic phosphorus source plays a large role in whether phosphorus requirements can be met through the enzymatic liberation of phosphorus from organic compounds.

\section{CONCLUSIONS}

Efficient Aphanizomenon flos-aquae growth during summer has to be supported by higher phosphate concentrations; the biomass maximum is thus frequently found just above the thermocline or in frontal regions where vertical advection occurs. A. flos-aquae has also been noted to grow more efficiently in low light than Nodularia spumigena during phosphorusreplete conditions, emphasizing the difference. The results thus strengthen the conception, based on field studies, that under bloom conditions $N$. spumigena is a superior competitor for phosphorus at low concentrations. It is more efficient in acquiring phosphate from organic sources and grows better on intracellular phosphorus stores. 
There is a difference between Aphanizomenon flosaquae and Nodularia spumigena phosphorus acquisition strategies. A. flos-aquae is dependent on a sufficient DIP supply. A. flos-aquae growth is eurythermal, and summer blooms already have relatively large inocula in surface waters during spring and early summer, allowing substantial biomasses to form. The internal loading of phosphorus that has been a recurrent phenomenon in the Gulf of Finland since the mid-1990s, and also in the Baltic Proper in recent years, will most likely especially promote the growth of A. flos-aquae. $N$. spumigena growth is more independent of a DIP supply, allowing it to thrive in more stratified and inert near-surface layers, with organic compounds and efficient phosphorus recycling being the main phosphorus supplies.

Acknowledgements. We are grateful for the efficiency and enthusiasm of E. Eronen, who assisted in the laboratory work. We thank A. Nurmi for the numerous nutrient analyses, J. Vahtera for valuable discussions on the statistical analyses and Academy Professor K. Sivonen for providing us with the strains. We also thank the 3 anonymous reviewers and Harri Kuosa and Hermanni Kaartokallio for valuable comments on the manuscript. The Maj and Tor Nessling foundation granted the funding for this work.

\section{LITERATURE CITED}

Conley DJ, Humborg C, Rahm L, Savchuk OP, Wulff F (2002) Hypoxia in the Baltic Sea and basin-scale changes in phosphorus biogeochemistry. Environ Sci Technol 36:5315-5320

Evans AM, Gallon JR, Jones A, Staal M, Stal LJ, Villbrandt M, Walton TJ (2000) Nitrogen Fixation by Baltic cyanobacteria is adapted to the prevailing photon flux density. New Phytol 147:285-297

Fu FX, Zhang Y, Leblanc K, Sañudo-Wilhelmy SA, Hutchins DA (2005a) The biological and biogeochemical consequences of phosphate scavenging onto phytoplankton cell surfaces. Limnol Oceanogr 50:1459-1472

Fu FX, Zhang YH, Bell PRF, Hutchins DA (2005b) Phosphate uptake and growth kinetics of Trichodesmium (Cyanobacteria) isolates from the North Atlantic Ocean and the Great Barrier Reef, Australia. J Phycol 41:62-73

Granéli E, Wallström K, Larsson U, Granéli W, Elmgren R (1990) Nutrient limitation of primary production in the Baltic Sea area. Ambio 19:142-151

Grönlund L, Kononen K, Lahdes E, Mäkelä K (1996) Community development and modes of phosphorus utilization in a late summer ecosystem in the central Gulf of Finland, the Baltic Sea. Hydrobiologia 331:97-108

Heinänen A, Kuparinen J (1992) Response of bacterial thymidine and leucine incorporation to nutrient $\left(\mathrm{NH}_{4}, \mathrm{PO}_{4}\right)$ and carbon (sucrose) enrichment. Arch Hydrobiol Beih Ergeb Limnol 37:241-251

Huber AL (1986) Nitrogen fixation by Nodularia spumigena Mertens (Cyanobacteriaceae). 2. Laboratory studies. Hydrobiologia 133:193-202

Huber AL, Hamel KS (1985) Phosphatase activities in relation to phosphorus nutrition in Nodularia spumigena
(Cyanobacteriaceae). 2. Laboratory studies. Hydrobiologia 123:81-88

Jansen F, Neumann T, Schmidt M (2004) Inter-annual variability in cyanobacteria blooms in the Baltic Sea controlled by wintertime hydrographic conditions. Mar Ecol Prog Ser 275:59-68

Janson S, Carpenter EJ, Bergman B (1994) Fine structure and immonulocalisation of proteins in Aphanizomenon sp. from the Baltic Sea. Eur J Phycol 29:203-211

Jensen MO, Moestrup O (1999) Ultrastructure of Chrysochromulina ahrengotii sp. nov. (Prymnesionphyceae), a new saddle-shaped species of Chrysochromulina from Danish coastal waters. Phycologia 38:195-207

Kahru M, Horstmann U, Rud O (1994) Satellite detection of increased cyanobacteria blooms in the Baltic Sea: natural fluctuation or ecosystem change? Ambio 23:469-472

Kahru M, Leppänen JM, Rud O, Savchuk OP (2000) Cyanobacteria blooms in the Gulf of Finland triggered by saltwater inflow into the Baltic Sea. Mar Ecol Prog Ser 207:13-18

Kangro K, Olli K, Tamminen T, Lignell R (2007) Species-specific responses of a cyanobacteria-dominated phytoplankton community to artificial nutrient limitation: a Baltic Sea coastal mesocosm study. Mar Ecol Prog Ser (in press)

Kanoshina I, Lips U, Leppänen JM (2003) The influence of weather conditions (temperature and wind) on cyanobacterial bloom development in the Gulf of Finland (Baltic Sea). Harmful Algae 2:29-41

Kononen K, Nômmann S (1992) Spatio-temporal dynamics of the cyanobacterial blooms in the Gulf of Finland, Baltic Sea. In: Carpenter EJ, Capone DG, Rueter JG (eds) Marine pelagic cyanobacteria: Trichodesmium and other diazotrophs, Vol 362. Kluwer Academic Publishers-NATO ASI, Dordrecht, p 95-113

Kononen K, Lahdes EO, Grönlund L (1993) Physiological and community responses of summer plankton to nutrient manipulation in the Gulf of Finland (Baltic Sea) with special reference to phosphorus. Sarsia 78:243-253

Kononen K, Kuparinen J, Mäkelä K, Laanemets J, Pavelson J, Nômmann $S$ (1996) Initiation of cyanobacterial blooms in a frontal region at the entrance to the Gulf of Finland, Baltic Sea. Limnol Oceanogr 41:98-112

Kononen K, Hällfors S, Kokkonen M, Kuosa H, Laanemets J, Pavelson J, Autio R (1998) Development of a subsurface chlorophyll maximum at the entrance to the Gulf of Finland, Baltic Sea. Limnol Oceanogr 43:1089-1106

Koroleff F (1983) Determination of phosphorus. In: Grasshoff $\mathrm{K}$, Ehrhardt M, Kremling $\mathrm{K}$ (eds) Methods of seawater analysis. Verlag Chemie, Weinheim, p 125-134

Kromkamp J (1987) Formation and functional significance of storage products in cyanobacteria. NZ J Mar Freshw Res 21:457-465

Kuparinen J, Heinänen A (1993) Inorganic nutrient and carbon controlled bacterioplankton growth in the Baltic Sea. Estuar Coast Shelf Sci 37:271-285

Laamanen M, Kuosa H (2005) Annual variability of biomass and heterocysts of the $\mathrm{N}_{2}$-fixing cyanobacterium Aphanizomenon flos-aquae in the Baltic Sea with reference to Anabaena spp. and Nodularia spumigena. Boreal Environ Res 10:19-30

Laanemets J, Kononen K, Pavelson J, Poutanen EL (2004) Vertical location of seasonal nutriclines in the western Gulf of Finland. J Mar Syst 52:1-13

Laanemets J, Lilover MJ, Raudsepp U, Autio R, Vahtera E, Lips I, Lips U (2006) A fuzzy logic model to describe the cyanobacteria Nodularia spumigena blooms in the Gulf of Finland, Baltic Sea. Hydrobiologia 554:31-45 
Larsson U, Hajdu S, Walve J, Elmgren R (2001) Baltic Sea nitrogen fixation estimated from the summer increase in upper mixed layer total nitrogen. Limnol Oceanogr 46:811-820

Lehtimäki J, Moisander P, Sivonen K, Kononen K (1997) Growth, nitrogen fixation, and nodularin production by two Baltic Sea cyanobacteria. Appl Environ Microbiol 63:1647-1656

Moisander PH, Steppe TF, Hall NS, Kuparinen J, Paerl HW (2003) Variability in nitrogen and phosphorus limitation for Baltic Sea phytoplankton during nitrogen-fixing cyanobacterial blooms. Mar Ecol Prog Ser 262:81-95

Nausch M, Nausch G (2004) Bacterial utilization of phosphorus pools after nitrogen and carbon amendment and its relation to alkaline phosphatase activity. Aquat Microb Ecol 37:237-245

Nausch M, Nausch G, Wasmund N (2004) Phosphorus dynamics during the transition from nitrogen to phosphate limitation in the central Baltic Sea. Mar Ecol Prog Ser 266:15-25

Niemistö L, Rinne I, Melvasalo T, Niemi ^̊ (1989) Blue-green algae and their nitrogen fixation in the Baltic Sea in 1980, 1982 and 1984. Meri-Rep Ser Finn Inst Mar Res 17:3-59

Panosso R, Granéli E (2000) Effects of dissolved organic matter on the growth of Nodularia spumigena (Cyanophyceae) cultivated under $\mathrm{N}$ or $\mathrm{P}$ deficiency. Mar Biol 136:331-336

Petterson K (1980) Alkaline phosphatase activity and algal surplus phosphorus as phosphorus-deficiency indicators in Lake Erken. Arch Hydrobiol 89:54-87

Raateoja M, Seppälä J, Kuosa H, Myrberg K (2005) Recent changes in trophic state of the Baltic Sea along SW coast of Finland. Ambio 34:188-191

Rydin E, Hyenstrand P, Gunnerhed M, Blomqvist P (2002) Nutrient limitation of cyanobacterial blooms: an enclosure experiment from the coastal zone of the NW Baltic proper. Mar Ecol Prog Ser 239:31-36

Editorial responsibility: Fereidoun Rassoulzadegan, Villefranche-sur-Mer, France
Sañudo-Wilhelmy SA, Tovar-Sanchez A, Fu FX, Capone DG, Carpenter EJ, Hutchins DA (2004) The impact of surfaceadsorbed phosphorus on phytoplankton Redfield stoichiometry. Nature 432:897-901

Sivonen K, Kononen K, Esala AL, Niemelä SI (1989) Toxicity and isolation of the cyanobacterium Nodularia spumigena from the southern Baltic Sea in 1986. Hydrobiologia 185:3-8

Stal LJ, Staal M, Villbrandt M (1999) Nutrient control of cyanobacterial blooms in the Baltic Sea. Aquat Microb Ecol 18:165-173

Stoecker D, Autio R, Rintala JM, Kuosa H (2005) Ecto-cellular enzyme activity associated with filamentous cyanobacteria. Aquat Microb Ecol 40:151-161

Struck U, Emeis KC, Voss M, Christiansen C, Kunzendorf H (2000) Records of southern and central Baltic Sea eutrophication in $\delta^{13} \mathrm{C}$ and $\delta^{15} \mathrm{~N}$ of sedimentary organic matter. Mar Geol 164:157-171

Suikkanen S, Laamanen M, Huttunen M (2007) Long-term changes in summer phytoplankton communities of the open northern Baltic Sea. Estuar Coast Shelf Sci 71:580-592

Tamminen T (1989) Dissolved organic phosphorus regeneration by bacterioplankton: 5'-nucleotidase activity and subsequent phosphate uptake in a mesocosm enrichment experiment. Mar Ecol Prog Ser 58:89-100

Thompson PA, Oh HM, Rhee GY (1994) Storage of phosphorus in nitrogen-fixing Anabaena flos-aquae (Cyanophyceae). J Phycol 30:267-273

Vahtera E, Laanemets J, Pavelson J, Huttunen M, Kononen K (2005) Effect of upwelling on the pelagic environment and bloom-forming cyanobacteria in the western Gulf of Finland, Baltic Sea. J Mar Syst 58:67-82

Voss M, Larsen B, Leivuori M, Vallius H (2000) Stable isotope signals of eutrophication in Baltic Sea sediments. J Mar Syst 25:287-298

Wallström K, Johansson S, Larsson U (1992) Effect of nutrient enrichment on planktonic blue-green algae in the Baltic Sea. Acta Phytogeogr Suec 78:25-31

Submitted: June 20, 2006; Accepted: January 8, 2007 Proofs received from author(s): February 28, 2007 